Research Article

\title{
Effect of Bacillus cohnii on Some Physicomechanical and Microstructural Properties of Ordinary Portland Cement
}

\author{
Ngari Reginah Wangui $\mathbb{D}^{1},{ }^{1}$ Joseph Karanja Thiong'o, ${ }^{1}$ and Jackson Muthengia Wachira $\mathbb{i D}^{2}$ \\ ${ }^{1}$ Department of Chemistry, Kenyatta University, Nairobi, Kenya \\ ${ }^{2}$ Department of Physical Sciences, University of Embu, Embu, Kenya \\ Correspondence should be addressed to Ngari Reginah Wangui; ngarireginah@gmail.com
}

Received 8 August 2020; Revised 7 September 2020; Accepted 14 September 2020; Published 27 September 2020

Academic Editor: Nenad Ignjatovi

Copyright ( $) 2020$ Ngari Reginah Wangui et al. This is an open access article distributed under the Creative Commons Attribution License, which permits unrestricted use, distribution, and reproduction in any medium, provided the original work is properly cited.

\begin{abstract}
Cement-made materials face durability and sustainability challenges. This is majorly caused by the presence of cracks. Cracking affects the mechanical strength of cement-based materials. Microbiologically induced calcite precipitation (MICP) has been found to enhance compressive strength, thus enhancing on the mechanical and durability properties of these materials. This paper presents the findings of a study conducted to investigate the effect of Bacillus cohnii on compressive strength development of OPC mortar prisms and the effect of Bacillus cohnii on cement setting time and soundness. Microbial concentration of $1.0 \times 10^{7}$ cells. $\mathrm{ml}^{-1}$ was used. Compressive strength tests analyses were carried out for each category of mortar prisms. Compressive strength tests were carried out on the $2^{\text {nd }}, 7^{\text {th }}, 14^{\text {th }}, 28^{\text {th }}, 56^{\text {th }}$, and $90^{\text {th }}$ day of curing in distilled water and microbial solutions. All microbial mortars exhibited a greater compressive strength compared to the control with the highest observed at 90 days. Highest percentage gain in compressive strength was observed at 90 days which is $28.3 \%$. Microstructural analysis was carried out using a scanning electron microscope (SEM) after 28 days of curing. The results indicated the presence of calcium carbonate and more calcium silicate hydrate (CSH) deposits on the bacterial mortars. The bacteria did not have an effect on cement soundness. Setting time was significantly accelerated.
\end{abstract}

\section{Introduction}

There is an increasing need to enhance the durability and sustainability of cement-made materials. These materials are expected to have a long service life of more than fifty years [1]. However, due to degradation, this is sometimes impossible [2]. Due to this, there is a need for continuous monitoring and repair of cement-made materials which is expensive in the long run [3].

To a great extent, durability aspects of mortar/concrete are possibly connected with its pore structure characteristics [4]. Deleterious processes, such as rebar corrosion, caused by ingress of chloride or carbonation, are aided by connectivity within the pore system of the cement matrix. The vulnerability of these cement-based materials to the deleterious processes is more if the pore structure is more open and interconnected $[5,6]$. Densification of the cement matrix microstructure is one method of sealing the pores. This increases the resistance of the material for ingress of the deleterious materials such as $\mathrm{CO}_{2}$, chlorides, and sulphates [7].

Ordinary Portland cement (OPC) exhibits shorter setting times and achieves high compressive strength earlier (at 28 days of curing) compared to blended cements [8]. Due to these properties, OPC is preferred in the construction of dams and bridges in Kenya [8, 9]. OPC is, however, prone to attack by deleterious substances such as chlorides and sulphates because of high amount of $\mathrm{Ca}(\mathrm{OH})_{2}$ released as a hydration product [8]. The pore structure of OPC is more open compared to that of blended cement structures $[9,10]$. Hence, there is a need for densification and refinement of its microstructure. Cement-made structures using OPC have a higher permeability due to their higher tendency to form cracks. These cracks tend to form a continuous pathway for 
ingress of aggressive media/deleterious substances. Their presence is thus undesirable in these cement-based materials since they are a major cause of deterioration and which compromises durability [9].

Measures aimed at crack remediation in cement-based materials are therefore being undertaken to ensure serviceability of the structures [11]. In this regard, a novel technique that uses bacterial sealing in which bacterial metabolism aids in calcite precipitation has been utilized [12]. Urea hydrolyzing bacteria has been explored, hence the name bacterial concrete. Bacteria in cement give it a special ability to repair itself autonomously [13]. Bacteria incorporation in cement also aids in improving the inherent characteristics of cement-made materials in most environments [14].

Long-term durability and sustainability of cement-based materials is important in order to avert economic losses and safety considerations [1]. Deterioration of cement-made materials is mainly triggered by ingress of aggressive substances [2]. The downgrading of cement-based materials/ structures durability and mechanical aspects is influenced majorly by its pore structure [15]. Application of MICP has been found to be an environmentally innocuous process in enhancing the properties of cement $[3,15]$. Researchers $[16,17]$ have established that MICP enhances strength of bricks and consolidating sand. They [16, 17] further noted that permeability aspects of concrete were also improved [15]. This is by decreasing water and chloride ion permeability by sealing/plugging the small holes and cracks in concrete $[15,18]$. Incorporation of microorganisms in mortar/concrete enables self-healing and enhances other durability characteristics of mortar/concrete that would save the environment [19]. This is possible since other materials, for example, chloride salts, used in strength enhancement and improvement of durability are not environmental friendly [11]. The materials are expensive compared to microbial concrete; require regular maintenance; as well as limited availability $[1,11]$.

MICP mainly depends upon $\mathrm{pH}$ as well as presence of growth site among other factors [20, 21]. The MICP process is also influenced by $\mathrm{Ca}^{2+}$ ion concentration as well as dissolved inorganic carbon [22]. Studies by Balazas [21] and Chahal et al. [23] using concrete demonstrated that the optimum cell concentration of Bacillus subtilis was $10^{6}$ cells per ml. Leena and Vishakha [24] used Bacillus cohnii and observed a $15 \%$ gain in compressive strength in relation to the control.

\section{Materials and Methods}

\subsection{Materials}

2.1.1. Chemical Analysis of Test Cement. In this investigation, standard sand and OPC $\left(42.5 \mathrm{~N} / \mathrm{mm}^{2}\right)$ cement were used manufactured in compliance with ISO 679:1989, EN 196-1 [25]. Analysis was performed in accordance with KS EAS 18-1:2017 [26]. 100.0 g was pulverized and ground to pass through a $76 \mu \mathrm{m}$ sieve. XRF was used to analyze the oxides in the cement.
2.1.2. Loss on Ignition (LOI). Triplicate samples of test cement were analyzed for loss on ignition (LOI). Gravimetric method described in KS EAS 18:1-2017 [26] was used to determine LOI. $1.000 \mathrm{~g}$ of the test cement was accurately weighed and put into a crucible whose mass had been predetermined. The crucible and its content were placed in a furnace preset at $975^{\circ} \mathrm{C}$. This was done for one hour after which the crucible and its content were removed from the furnace and cooled in a desiccator. LOI was expressed as a percentage of the difference of the mass before and after ignition.

Chemical composition of test cement is given in Table 1.

From the results, the test cement met the stipulated requirement by Kenya Bureau of Standards [26].

2.1.3. Nutrients for Bacterial Culturing. Analytical grade (AR) chemicals were used in this work. They were acquired from Highway Laboratory Chemical Equipment, Nairobi, Kenya. These included peptone from casein, calcium lactate, sodium hydrogen carbonate, distilled water, meat extract, and anhydrous sodium carbonate. Bacillus cohnii was sourced from Germany, Leibniz-Institut DSMZ-Deutsche Sammlung von Mikroorganismen und Zellkulturen $\mathrm{GmbH}$.

2.1.4. Microbial Cultivation of Bacillus cohnii. Microbial solution of Bacillus cohnii was cultured as stipulated in the manual from the supplier (Leibniz-Institut DSMZ-Deutsche Sammlung von Mikroorganismen und Zellkulturen $\mathrm{GmbH}$ ). The media (liquid) considered for the culturing the bacteria was constituted by adding $5.00 \mathrm{~g}$ of peptone to $3.95 \mathrm{~g}$ of calcium acetate and $3.00 \mathrm{~g}$ of meat extract in 1 litre of distilled water. The resultant mixture constituted the liquid medium per stock culture. Sterilization of the mixture was carried out by autoclaving at a temperature of $121^{\circ} \mathrm{C}$. This was done for 20 minutes. This mixture was then cooled to room temperature. $5.30 \mathrm{~g}$ of anhydrous $\mathrm{Na}_{2} \mathrm{CO}_{3}$ and $4.20 \mathrm{~g}$ of $\mathrm{NaHCO}_{3}$ were mixed and a solution of one litre prepared which was $1 \mathrm{M} \mathrm{Na}$-sesquicarbonate $(1.0 \mathrm{ml}$ in $10.0 \mathrm{ml})$ and then added to the stock culture, and this adjusted the $\mathrm{pH}$ of the stock solution to 9.7. At this $\mathrm{pH}$, bacterium spore powder was added to the mixture. Using a shaker incubator and at 130 rotations per minute, these cultures were incubated for 72 hours at a temperature of $30^{\circ} \mathrm{C}$. Using an atomic absorbance spectrophotometer (G10S UV-Vis, USA), test for optical density (OD) was performed to determine the amount of culture solution required to mix so as to achieve the desired concentration. Bacterium growing media was considered as the blank sample for checking the microbial solutions. $0.5 \mathrm{ml}$ of both the blank and microbial solution was separately put in the spectrophotometer set at a wavelength of 600 nanometres, and the machine was set to read. $1.0 \times 10^{7}$ cells $\cdot \mathrm{ml}^{-1}$ was recorded as the concentration and used in this investigation.

2.1.5. Preparation of Mortar Prisms. Test prisms were prepared using $40 \mathrm{~mm} \times 40 \mathrm{~mm} \times 160 \mathrm{~mm}$ moulds according to KS EAS 18-1:2017 [26]. To prepare mortar with $w / c$ of 0.5 , 
TABle 1: Chemical composition of test cement.

\begin{tabular}{lc}
\hline Oxide (\%) & OPC \\
\hline $\mathrm{SiO}_{2}$ & $22.15 \pm 0.41$ \\
$\mathrm{Al}_{2} \mathrm{O}_{3}$ & $3.89 \pm 0.08$ \\
$\mathrm{Fe}_{2} \mathrm{O}_{3}$ & $3.31 \pm 0.13$ \\
$\mathrm{CaO}$ & $65.89 \pm 0.07$ \\
$\mathrm{MgO}$ & $1.25 \pm 0.44$ \\
$\mathrm{SO}$ & $2.21 \pm 0.16$ \\
$\mathrm{~K}_{2} \mathrm{O}$ & $0.60 \pm 0.07$ \\
$\mathrm{Na}_{2} \mathrm{O}$ & $0.27 \pm 0.04$ \\
$\mathrm{LOI}$ & $1.64 \pm 0.15$ \\
\hline
\end{tabular}

$450 \pm 1 \mathrm{~g}$ of OPC cement was put in a mix basin of a mixer model number 1616-6-1358 at East African Portland Cement Company Limited, Athi River, Kenya. $225.0 \mathrm{ml}$ of distilled water was added to the cement in the basin. The mix basin was then clamped onto the automatic mixer, and $1350 \pm 1 \mathrm{~g}$ of standard sand was added little by little till all was added from an automatic pour trough. The resultant mortar was used to prepare three prisms. The cast prisms were stored in a humidity cabinet for 24 hours at $22^{\circ} \mathrm{C} \pm 1^{\circ} \mathrm{C}$ and then demolded. The demolded mortars were labeled and cured in their respective curing media.

2.1.6. Soundness Test. The test was performed according to KS EAS 148-3:2017 [27]. A lightly oiled mould was put on a lightly oiled glass sheet and filled with mortar paste formed by gauging cement with 0.78 times the distilled water to prepare the control cement paste labeled as $\mathrm{OPC}\left(\mathrm{H}_{2} \mathrm{O}\right)$. The same steps were followed but with 0.78 times of bacterial solution and denoted as OPC (BC). This gave a cement paste of standard consistency for each mortar category. This was done in triplicates.

\subsubsection{Setting Time}

(1) Initial Setting Time and Final Setting Time. Fresh cement pastes for the control and microbial were prepared according to KS EAS 148-3:2017 [27]. This was done in triplicates for both initial and final setting time, and their average was reported.

\subsection{Methods}

2.2.1. Compressive Strength Analysis. Compressive strength analysis was conducted according to KS EAS 148-3:2017 [27]. This was done at $2^{\text {nd }}, 7^{\text {th }}, 14^{\text {th }}, 28^{\text {th }}, 56^{\text {th }}$, and $90^{\text {th }}$ day of curing the control and microbial mortar prisms. Analysis was performed using a compressive strength machine number $\mathrm{CH}$ 8224lohningent. Three mortar prisms for each mortar category were picked from the curing tub and wiped off any deposits. They were placed on the testing machine after noting their identities and load applied vertically at a rate of $50 \mathrm{~N} / \mathrm{s}$ until failure to obtain prism halves. The obtained halves were smoothly crushed by load application at $2400 \mathrm{~N} / \mathrm{s}$. The average strength of the three prisms was considered as the final compressive strength.
2.2.2. Scanning Electron Microscopy (SEM). SEM was performed on control and microbial samples after $28^{\text {th }}$ day of curing. This was done using the SEM model Zeiss Ultra Plug FEG-SEM according to Scrivener et al. [28].

\section{Results and Discussion}

3.1. Setting Time and Soundness. Table 2 gives the results for setting time and soundness for the control and microbial cement samples.

From the results, the initial and final setting times of the control were observed as 78 and 165 minutes, respectively. The initial setting time was accelerated by 15 minutes when compared with the control. The findings indicated that both initial and final setting times were significantly accelerated by Bacillus cohnii. The soundness was not affected by the bacteria.

3.2. Compressive Strength. Figures 1-3 presents the compressive strength results for the control and microbial mortar prisms at varied curing period and curing regimes as outlined in Section 2.1.3.

Table 3 gives the results of comparison of compressive strength development of the mortars with curing age.

The control mortars, labeled as OPC- $\mathrm{H}_{2} \mathrm{O}-\mathrm{H}_{2} \mathrm{O}$, met the recommended strength at 28 days of $42.5 \mathrm{MPa}$ as depicted in Figure 1 [26]. There was an observed increase in compressive strength of the mortar prisms as curing period increased for all mortars irrespective of the curing regime with the highest observed at 90 days as shown in Figure 1. It was observed that the increase was statistically significant from $14^{\text {th }}$ to $28^{\text {th }}$ day of curing for all categories of mortar prisms. This was expected because cement hydration reactions progresses with time of curing period [29]. It was observed that the increase in compressive strength increased from $28^{\text {th }}$ to $90^{\text {th }}$ day as the control mortars was statistically insignificant. This was attributed due to the fact that OPC develops strength early and gains over $90 \%$ of its strength by the $28^{\text {th }}$ day [29]. Similar observations were made by Thiyagarajan et al. [30]. It was observed that microbial mortars labeled as $\mathrm{OPC}-\mathrm{H}_{2} \mathrm{O}$ $\mathrm{BC}$, OPC-BC- $\mathrm{H}_{2} \mathrm{O}$, and OPC-BC-BC recorded a higher compressive strength compared to the control mortars at all the curing ages as depicted in Figure 1. This was attributed to the metabolic activities of Bacillus cohnii. It was observed that across all the curing periods, OPC-BC-BC mortar category registered the highest compressive strength. The highest was recorded as $65.8 \mathrm{MPa}$ at 90 days as shown in Figure 1 . This was attributed to more $\mathrm{Ca}^{2+}$ availed by both the mix media and curing media as compared to other mortar categories. This would then imply more MICP, hence more calcium carbonate and more CSH. The bacteria aided in the formation of more $\mathrm{CSH}$ and precipitating calcium carbonate through MICP process [31]. This calcium carbonate acted as a sealant and was able to plug the pore within the microstructure, and this improved compressive strength [32]. Mortars cast and cured in microbial solution recorded the highest compressive strength across all the mortar categories. Mutitu et al. [33] made similar observation using 
TABLE 2: Setting time and soundness for the control and microbial samples.

\begin{tabular}{lccc}
\hline \multirow{2}{*}{ Test cement } & \multicolumn{2}{c}{ Setting time (minutes) } & Soundness $(\mathrm{mm})$ \\
& Initial & Final & \\
\hline OPC $\left(\mathrm{H}_{2} \mathrm{O}\right)$ & $97.0 \pm 5.0$ & $179.0 \pm 5.0$ & $1.0 \pm 0.05$ \\
OPC $(\mathrm{BC})$ & $78.0 \pm 5.0$ & $165.0 \pm 5.0$ & $1.0 \pm 0.05$ \\
\hline
\end{tabular}

Lysinibacillus sphaericus bacteria. The mortar cast with distilled water and cured in microbial solution recorded the lowest compressive strength. This observation was consistent with the findings made by Jonkers et al. [34], Chaurasia et al. [31], and Van Tittelboom et al. [35]. It was noted that compressive strength of the microbial mortars did not differ statistically significantly between the $28^{\text {th }}$ and $56^{\text {th }}$ day. This was attributed to the stationary phase of bacterial growth as explained by Skarstad et al. [36] and Zwietering et al. [37] and also reduction of microbial population as the microbes were being coated with a layer of $\mathrm{CaCO}_{3}$ as a result of MICP process $[11,31]$. However, there was an observed statistically significant difference in the increase of compressive strength of all the microbial mortars between the $56^{\text {th }}$ and $90^{\text {th }}$ day. This was attributed to log/exponential phase of the bacteria as explained by Skarstad et al. [36] and Zwietering et al. [37]. The bacteria at that point is said to experience optimal growth and multiply faster [30].

Table 4 presents the results for Bacillus cohnii percentage gain in compressive strength of mortars.

Percentage gain in compressive strength was exhibited across all mortar categories in the range of $1.1 \%$ to $28.3 \%$. This was found to increase as curing period increased [29]. The highest percentage gain was noted on the $90^{\text {th }}$ day as $28.3 \%$. The difference in gain compressive strength was statistically significant between the $14^{\text {th }}$ day and $90^{\text {th }}$ day, and this was noted with all mortar categories. This was attributed to microbial activity of MICP process. The lowest gain in strength was recorded at 14 days. This was attributed to probably inability of the microbe to precipitate substantive amount of calcium carbonate and also aid in formation of CSH as it was adapting to the new environmental conditions within the cement mortar matrix [33]. This is the lag phase of bacterial growth, and as reported by Skarstad et al. [36], the bacteria are adapting to the new environment. However, gain in strength progressively increased after 14 days, and this could imply that the microbe had adapted to the new environment. The presence of other products such as calcium carbonate in addition to $\mathrm{CSH}$, which is majorly responsible for strength of cement, meant that more voids were sealed/plugged [29]. From SEM images, Figures 4-6, they show massive deposits of $\mathrm{CaCO}_{3}$ and more CSH as compared to Figure 3. The additional products might have been deposited in the voids, thus sealing them $[9,10]$.

Figures 3-6 present the SEM results. Figure 3 represents the SEM image for the control, labeled as OPC- $\mathrm{H}_{2} \mathrm{O}-\mathrm{H}_{2} \mathrm{O}$. Figures 4-6 represent mortars cast with distilled water and cured in microbial solution, denoted as $\mathrm{OPC}-\mathrm{H}_{2} \mathrm{O}-\mathrm{BC}$, mortars cast with microbial water and cured in distilled water labeled as OPC-BC- $\mathrm{H}_{2} \mathrm{O}$, and mortars cast and cured with microbial solution noted as OPC-BC-BC, respectively.

The images show the presence of calcium silicate hydrate, $\mathrm{C}_{3} \mathrm{~S}_{2} \mathrm{H}_{3},(\mathrm{CSH})$, calcium carbonate, $\left(\mathrm{CaCO}_{3}\right)$, ettringite $\left(\mathrm{C}_{6} \mathrm{AS}_{3} \mathrm{H}_{32}\right.$, needle-like crystals), and calcium hydroxide (Portlandite, $\mathrm{CH}$ ). Some ettringite was observed as needlelike-shaped crystals, and this was attributed to gypsum added to cement to control flash setting. Their formation is given as follows [34]:

$$
\begin{aligned}
2 \mathrm{C}_{3}+6 \mathrm{H} & \longrightarrow \mathrm{C}_{3} \mathrm{~S}_{2} \mathrm{H}_{3}+3 \mathrm{CH} \\
2 \mathrm{C}_{3}+4 \mathrm{H} & \longrightarrow \mathrm{C}_{3} \mathrm{~S}_{2} \mathrm{H}_{3}+\mathrm{CH} \\
\mathrm{C}_{3}+3 \mathrm{C} \overline{\mathrm{C}} \mathrm{H}_{2}+26 \mathrm{H} & \longrightarrow \mathrm{C}_{6} \mathrm{AS}_{3} \mathrm{H}_{32}
\end{aligned}
$$

The ettringite is shown in Figures 3 and 4. The figures represent the control mortar denoted as $\mathrm{OPC}-\mathrm{H}_{2} \mathrm{O}-\mathrm{H}_{2} \mathrm{O}$ and mortar cast using distilled water and cured in microbial solution, denoted as $\mathrm{OPC}-\mathrm{H}_{2} \mathrm{O}-\mathrm{BC}$, respectively. This was attributed to perhaps the gypsum added during the manufacture of cement to control flash setting and improve on cement workability. However, ettringite was not observed in Figures 5 and 6 . This was attributed to the bacterial activity in forming more calcium carbonate that may have probably deposited on any ettringite formed. While calcium carbonate and $\mathrm{CSH}$ was observed across all the microbial mortars, OPC-BC-BC mortar image exhibited massive deposits of calcium carbonate and more $\mathrm{CSH}$ as shown in Figure 6. This could account for the higher compressive strength observed with this category of mortars as compared to others. The SEM image shows a more refined microstructure and more dense cement matrix with this category of mortar compared with others. This was attributed to more microbial cells and more $\mathrm{Ca}^{2+}$ from the feed available for metabolic activity of the bacteria. From the results, it can be elucidated that incorporating the bacteria in the mix media had more benefits than using distilled water.

During microbial cultivation, calcium acetate present in the feed brought in extra $\mathrm{Ca}^{2+}$ ions into the cement matrix. This enhanced the formation of more calcium silicate hydrate $(\mathrm{CSH})$ and precipitation of more calcium carbonate. The cell wall of the bacteria acted as a nucleation site and in the presence of $\mathrm{Ca}^{2+}$ ions availed by calcium acetate from the bacterial feed, crystallized out as CSH when they combined with precipitated $\mathrm{CO}_{3}{ }^{2-}$ ions $[33,38]$. Bacillus cohnii in this investigation improved compressive strength of OPC, and this could improve durability properties and sustainability of cement-based materials in long run. MICP of calcium carbonate in this case was attributed to oxidation of acetate by Bacillus cohnii. This is given as follows [33]:

$$
\begin{aligned}
& \mathrm{CH}_{3} \mathrm{COO}^{-}+2 \mathrm{O}_{2} \longrightarrow 2 \mathrm{CO}_{2}+\mathrm{OH}^{-}+\mathrm{H}_{2} \mathrm{O} \\
& \mathrm{CO}_{2}+\mathrm{OH}^{-} \longrightarrow \mathrm{HCO}_{3}{ }^{-} \\
& \mathrm{HCO}_{3}{ }^{-}+\mathrm{OH}^{-} \longrightarrow \mathrm{CO}_{3}{ }^{2-}+\mathrm{H}_{2} \mathrm{O} \\
& \mathrm{Ca}^{2+}+\text { bacterial cell } \longrightarrow \text { bacterial cell }-\mathrm{Ca}^{2+} \\
& \text { bacterial cell }-\mathrm{Ca}^{2+}+\mathrm{CO}_{3}{ }^{2-} \longrightarrow \text { cell }-\mathrm{CaCO}_{3}
\end{aligned}
$$




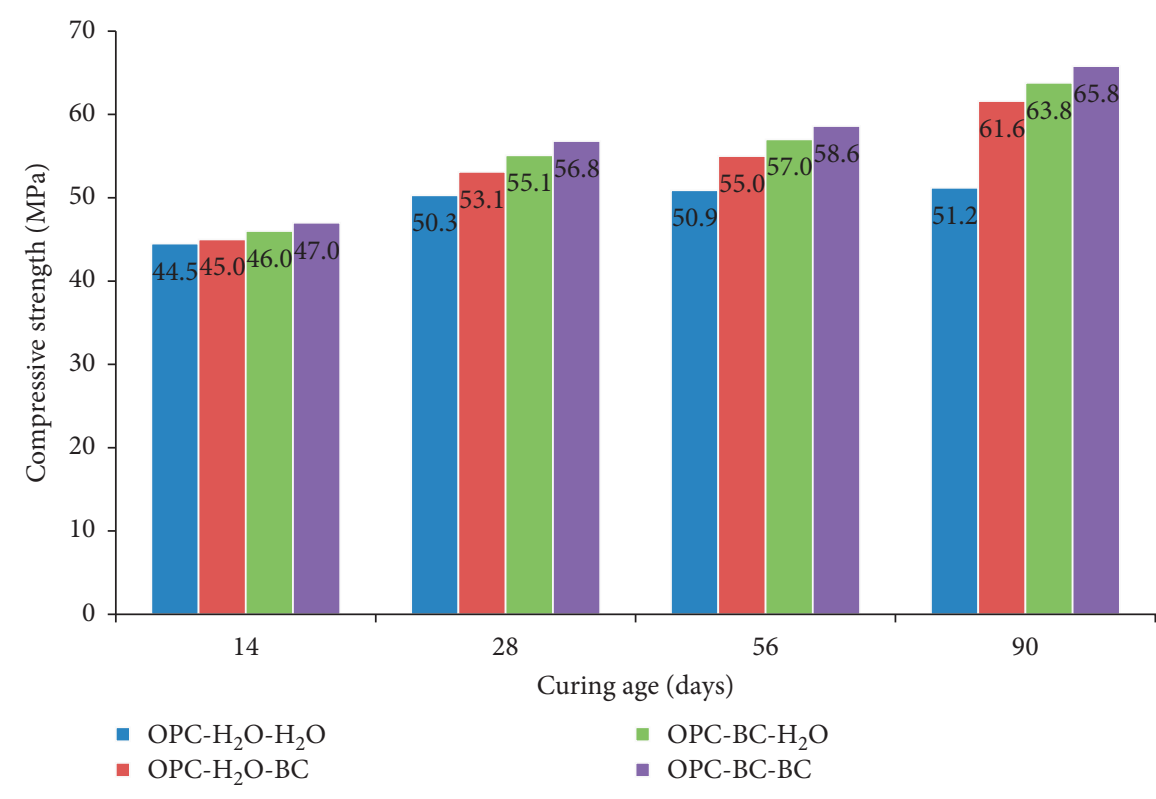

FIGURE 1: Test results for compressive strength for varied curing period.

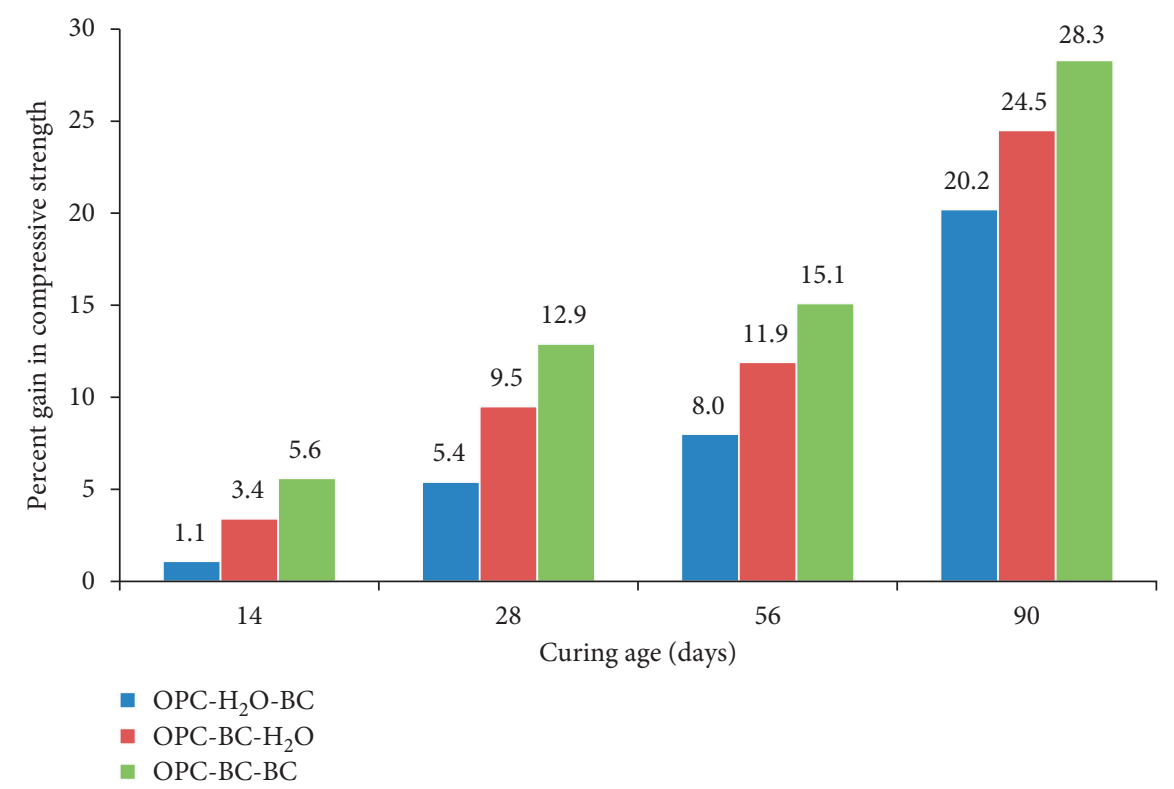

FIGURE 2: Results for percentage gain in compressive strength for different curing periods.

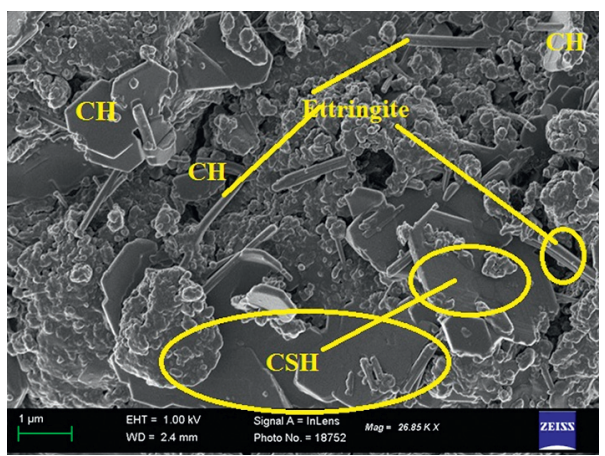

Figure 3: OPC- $\mathrm{H}_{2} \mathrm{O}-\mathrm{H}_{2} \mathrm{O}$. 
TABLE 3: Results of comparison of compressive strength development of mortar with curing age.

\begin{tabular}{lcccc}
\hline Curing age (days) & \multicolumn{3}{c}{ Compressive strength (mean \pm SE) MPa } \\
& OPC- $\mathrm{H}_{2} \mathrm{O}-\mathrm{H}_{2} \mathrm{O}$ & OPC- $\mathrm{H}_{2} \mathrm{O}-\mathrm{BC}$ & OPC-BC- $\mathrm{H}_{2} \mathrm{O}$ & OPC-BC-BC \\
\hline 14 & $44.50 \pm 1.40^{\mathrm{a}}$ & $45.00 \pm 1.00^{\mathrm{a}}$ & $46.01 \pm 1.15^{\mathrm{a}}$ & $47.00 \pm 0.74^{\mathrm{a}}$ \\
28 & $50.33 \pm 0.66^{\mathrm{b}}$ & $53.06 \pm 0.86^{\mathrm{b}}$ & $55.10 \pm 0.48^{\mathrm{b}}$ & $56.81 \pm 0.58^{\mathrm{b}}$ \\
56 & $50.94 \pm 0.28^{\mathrm{b}}$ & $55.04 \pm 0.83^{\mathrm{b}}$ & $57.01 \pm 0.07^{\mathrm{b}}$ & $58.61 \pm 0.68^{\mathrm{b}}$ \\
90 & $51.25 \pm 0.65^{\mathrm{b}}$ & $61.63 \pm 0.14^{\mathrm{c}}$ & $63.80 \pm 1.04^{\mathrm{c}}$ & $65.75 \pm 0.70^{\mathrm{c}}$ \\
\hline$p$ value & 0.001 & $<0.001$ & $<0.001$ & $<0.001$ \\
\hline
\end{tabular}

Mean values followed by the same small letter within the same column do not differ significantly from one another (one-way ANOVA, $\alpha=0.05$, SNK-test).

TABLE 4: Results for Bacillus cohnii percentage gain in compressive strength of mortars.

\begin{tabular}{|c|c|c|c|}
\hline \multirow[t]{2}{*}{ Curing age (days) } & \multicolumn{3}{|c|}{$\begin{array}{l}\text { Percent compressive strength gain } \\
\text { (mean } \pm \text { SE) } \%\end{array}$} \\
\hline & $\mathrm{OPC}-\mathrm{H}_{2} \mathrm{O}-\mathrm{BC}$ & $\mathrm{OPC}-\mathrm{BC}-\mathrm{H}_{2} \mathrm{O}$ & OPC-BC-BC \\
\hline 14 & $1.13 \pm 0.22^{\mathrm{a}}$ & $3.39 \pm 0.26^{\mathrm{a}}$ & $5.61 \pm 0.17^{\mathrm{a}}$ \\
\hline 28 & $5.42 \pm 0.17^{\mathrm{b}}$ & $9.47 \pm 0.10^{\mathrm{b}}$ & $12.88 \pm 0.12^{\mathrm{b}}$ \\
\hline 56 & $8.05 \pm 0.16^{\mathrm{b}}$ & $11.92 \pm 0.01^{\mathrm{b}}$ & $15.06 \pm 0.13^{\mathrm{b}}$ \\
\hline 90 & $20.25 \pm 0.03^{c}$ & $24.49 \pm 0.20^{c}$ & $28.29 \pm 0.14^{\mathrm{c}}$ \\
\hline$p$ value & $<0.001$ & $<0.001$ & $<0.001$ \\
\hline
\end{tabular}

Mean values followed by same small letters within the same column do not differ significantly from one another (one-way ANOVA, $\alpha=0.05$, SNKtest).

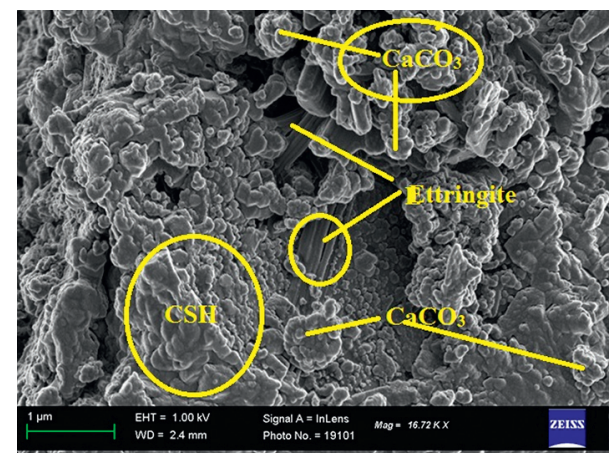

Figure 4: OPC- $\mathrm{H}_{2} \mathrm{O}-\mathrm{BC}$.

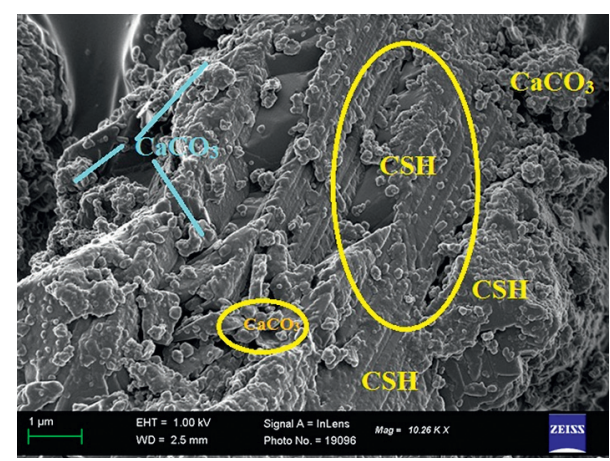

Figure 5: OPC-BC- $\mathrm{H}_{2} \mathrm{O}$.

Generally, integrating bacterium in the cement matrix had a beneficial effect on the compressive strength development. This, in long run, is expected to enhance other physical and mechanical aspects of microbial cement-made

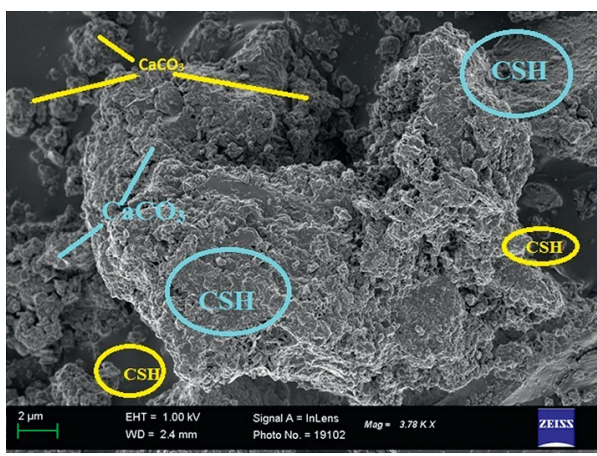

Figure 6: OPC-BC-BC.

materials. Flexural strength, resistivity to chloride, and sulphate ingress would be improved due to reduced permeability [39]. Thus, incorporation of Bacillus cohnii in the cement matrix improved the physicomechanical aspects of the material.

\section{Conclusion}

Bacillus cohnii precipitated substantive quantity of calcium carbonate capable of enhancing compressive strength and microstructure of the mortar matrix. The highest compressive strength gain was noted with OPCBC-BC mortar category, mortars cast and cured in microbial cultivated solution. Using microbial solution both as the mix and curing media yielded the highest benefits of microbial mortars. Bacillus cohnii enhanced the nucleation cites for MICP process resulting in enhanced overall microstructure of the mortar. The calcium acetate incorporated as a feed during bacterial cultivation introduced more $\mathrm{Ca}^{2+}$ within the mortar matrix which enhanced the formation of calcium carbonate which plugged into pores as shown by the SEM micrographs/ images enhancing compressive strength. The bacteria did not influence the soundness of cement. The setting time of cement was significantly accelerated.

\section{Data Availability}

The data used to support the findings of this study are available from the corresponding author upon request.

\section{Conflicts of Interest}

The authors declare no conflicts of interest. 


\section{Acknowledgments}

The authors recognize the immense support offered by East Africa Portland Cement Limited, Kenya, where the preparation of mortar prisms, compressive strength, setting time, and soundness tests analyses were carried out. Our appreciation is extended to Departments of Microbiology and Biochemistry, Agriculture, Chemistry all of Kenyatta University where cultivation of Bacillus cohnii was undertaken. Our gratitude is conveyed to Erna van Wilpe, Specialist Analytical Scientist-Laboratory Manager, and Laboratory for Microscopy and Microanalysis, University of Pretoria, South Africa, for facilitating SEM analysis. Financial support from the African Development Bank in collaboration with the Ministry of Education, Science, and Technology, Kenya, is highly acknowledged.

\section{References}

[1] H. P. Emmons and J. D. Sordy, "The state of concrete repair industry, and a vision for its future," Concrete Repair Bulletin, vol. 8, pp. 7-14, 2006.

[2] Ş. Erdoğdu, T. W. Bremner, and I. Kodratova, "Accelerated testing of plain and epoxy-coated reinforcement in simulated seawater and chloride solutions," Journal of Cement and Concrete Research, vol. 31, no. 6, pp. 861-867, 2001.

[3] S. Senot, "Can self-healing mechanism helps concrete structures sustainable?" Procedia Engineering, vol. 171, pp. 238-249, 2017.

[4] M. Luo and C. Qjan, "Influences of bacteria based self-healing agents on cementitious materials hydration kinetics and compressive strength," Construction and Building Materials, vol. 4, pp. 1132-1141, 2016.

[5] J. M. Wachira, "Effects of chlorides on corrosion of simulated reinforced blended cement mortars," International Journal of Corrosion, vol. 2019, Article ID 2123547, 7 pages, 2019.

[6] M. Meas and N. De Belie, "Service life estimation of cracked and healed concrete in marine environment," in Proceedings of the 6th International on Concrete Repair, Thessaloniki, Greece, June 2016.

[7] R. W. Ngari, "Sulphate and chloride ingress and the effect in selected cements mortar prisms immersed in sea water and leather industry effluent," M.Sc. thesis, Kenyatta University, Nairobi, Kenya, 2014.

[8] J. M. Marangu, J. K. Thiong'o, and J. M. Wachira, "Chloride ingress in chemically activated calcined clay-based cement," Journal of Chemistry, vol. 2018, Article ID 1595230, 8 pages, 2018.

[9] J. M. Wachira, R. W. Ngari, J. T. Karanja, and J. M. Mwiti, "Effect of sulphate and chloride ingress on selected cements mortar prisms immersed in seawater and leather industry effluent," Journal of Advances in Civil Engineering, vol. 2019, Article ID 8191689, 16 pages, 2019.

[10] R. K. Verma, L. Chaurasia, and V. Bisht, "Bio-mineralization and bacterial carbonate precipitation in mortar and concrete," Journal of Bioscience and Bioengineering, vol. 1, pp. 5-11, 2015.

[11] H. M. Jonkers, A. Thijssen, G. Muyzer, and O. Copuroglu, "Application of bacteria as self healing agent for the development of sustainable concrete," Ecological Engineering, vol. 4, pp. 1121-1129, 2011.

[12] F. C. Meldrum, "Calcium carbonate in biomineralisation and biomimetic chemistry," International Materials Reviews, vol. 48, no. 3, pp. 187-224, 2003.
[13] S. K. Ramachandran, V. Ramakrishnan, and S. S. Bang, "Remediation of concrete using microorganisms," ACI Material Journal, vol. 98, no. 1, pp. 3-9, 2001.

[14] J. L. Day, V. Ramakrishnan, and S. S. Bang, "Microbiologically induced sealant for concrete crack remediation," in Proceedings of 16th Engineering Mechanics Conference, Seattle, WA, USA, July 2003.

[15] T. Abhishek, P. Akshay, and S. Khushpreet, "Bacterial concrete and effect of different bacteria on the strength and water absorption characteristics of concrete: a review," International Journal of Civil Engineering and Technology, vol. 7, no. 5, pp. 43-56, 2016.

[16] K. K. Satinder, P. Manisha, and G. P. Urmila, "Study of strength variation of concrete using ureolytic bacteria," International Journal of Engineering and Applied Sciences (IJEAS), vol. 3, no. 4, pp. 81-84, 2016.

[17] B. Lian, Q. Hu, J. Chen, J. Ji, and H. H. Teng, "Carbonate biomineralization induced by soil bacterium Bacillus megaterium," Geochimica et Cosmochimica Acta, vol. 70, no. 22, pp. 5522-5535, 2006.

[18] G. T. Suthar and K. B. Parikh, "A study of microorganism (bacteria) on concrete strength and durability," International Journal for Technological Research in Engineering, vol. 3, no. 12, pp. 3185-3189, 2016.

[19] N. Chahal, R. Siddique, and A. Rajor, "Influence of bacteria on the compressive strength, water absorption and rapid chloride permeability of fly ash concrete," Construction and Building Materials, vol. 28, no. 1, pp. 351-356, 2012.

[20] W. Zhong and W. Yao, "Influence of damage degree on selfhealing of concrete," Construction and Building Materials, vol. 22 , no. 6, pp. 1137-1142, 2008.

[21] A. C. Balazas, "Modelling self-healing materials," Materials Today, vol. 10, pp. 18-23, 2007.

[22] V. C. Li and E. Yang, "Self healing in concrete materials," in Self Healing Materials-an Alternative Approach to 20 Centuries of Materials Science, S. van der Zwaag, Ed., pp. 161-194, Springer, Dordrecht, The Netherlands, 2007.

[23] N. Chahal, A. Rajor, and R. Siddique, "Calcium carbonate precipitation by different bacterial strains," African Journal of Biotechnology, vol. 10, pp. 8359-8372, 2011.

[24] C. Leena and B. Vishakha, "Resistance of bio-based cementitious materials to acid attack," International Journal of Current Research, 2014.

[25] EN 196-1, Cement Part 1: Composition, Specifications and Conformity Criteria for Common Cements, European Union Standards, Beckum, Germany, 2011.

[26] KS EAS 18-1, Kenya Standard Test Method for Oxides Specification of Hydraulic Cement, KEBS, Nairobi, Kenya, 2017.

[27] KS EAS 148-3, Cement-Test Methods Part 3: Determination of Setting Times and Soundness, Kenya Bureau of Standards, Nairobi, Kenya, 2017.

[28] K. Scrivener, R. Snellings, and B. Lothenbach, A Practical Guide to Microstructural Analysis of Cementitious Materials, CRC Press, Boca Raton, FL, USA, 1st edition, 2017.

[29] H. F. W. Taylor, Cement Chemistry, Taylor and Thomas Telford Services LTD, London, UK, 2nd edition, 1997.

[30] H. Thiyagarajan, M. Srinivasan, M. Mapa et al., "Investigation of bacterial activity on compressive strength of cement mortar in different curing media," Journal of Advanced Concrete Technology, vol. 14, pp. 25-133, 2016.

[31] R. K. Chaurasia, V. V. Verma, and V. Bisht, "Microbial carbonate precipitation by urease producing bacteria in cementitious materials," International Journal of Advanced Technology and Research, vol. 15, pp. 671-679, 2014. 
[32] S. Yoosathaporn, P. Tiangburanathamb, S. Bovonsombuta, A. Chaipanichc, and W. Pathom-aree, "A cost effective cultivation medium for biocalcification of Bacillus pasteurii KCTC 3558 and its effect on cement cubes properties," Microbiological Research, vol. 186, pp. 132-138, 2016.

[33] K. D. Mutitu, J. W. Muthengia, R. Mwirichia, J. T. Karanja, O. M. Mulwa, and G. Muriithi, "Influence of Lysinibacillus sphaericus on compressive strength and water sorptivity in microbial cement mortar," Heliyon, vol. 5, no. 11, Article ID e02881, 2019.

[34] H. M. Jonkers, A. Thijssen, O. Copuroglu, and E. Schlangen, "Application of bacteria as self-healing agent for development of sustainable concrete," in Proceedings of the 1st International Conference on BioGeoCivil Engineering, Delft, The Netherlands, June 2008.

[35] K. Van Tittelboom, N. De Belie, W. De Muynck, and W. Verstraete, "Use of bacteria to repair cracks," Cement and Concrete Research, vol. 40, no. 1, pp. 157-166, 2013.

[36] K. Skarstad, H. B. Steen, and E. Boye, "Cell cycle parameters of slowly growing escherichia coli b/r studied by flow cytometry," Journal of Bacteriology, vol. 154, no. 2, pp. 656-662, 1983.

[37] M. Zwietering, I. Jongenburger, F. Rombouts, and K. van't Riet, "Modelling of the bacterial growth curve," Applied and Environmental Microbiology, vol. 56, no. 6, pp. 1875-1881, 1994.

[38] Y. Ç. Erşan, N. Hernandez-Sanabra, N. Boon, and N. De Belie, "Enhanced crack closure performance of microbial mortar through nitrate reduction," Cement Concrete Research, vol. 70, pp. 159-170, 2015.

[39] O. M. Mulwa, J. K. Thiong'o, J. M. Wachira, D. K. Mutitu, and R. Mwirichia, "Influence of Starkeya novella on mechanical and microstructural properties of cement mortars," Journal of Chemistry, vol. 2020, Article ID 8212396, 9 pages, 2020. 